University of Nebraska - Lincoln

DigitalCommons@University of Nebraska - Lincoln

Summer 2000

\title{
The Omaha Gospel Complex In Historical Perspective
}

Tom Jack

College of Saint Mary

Follow this and additional works at: https://digitalcommons.unl.edu/greatplainsquarterly

Part of the Other International and Area Studies Commons

Jack, Tom, "The Omaha Gospel Complex In Historical Perspective" (2000). Great Plains Quarterly. 2155. https://digitalcommons.unl.edu/greatplainsquarterly/2155

This Article is brought to you for free and open access by the Great Plains Studies, Center for at DigitalCommons@University of Nebraska - Lincoln. It has been accepted for inclusion in Great Plains Quarterly by an authorized administrator of DigitalCommons@University of Nebraska - Lincoln. 


\title{
THE OMAHA GOSPEL COMPLEX IN HISTORICAL PERSPECTIVE
}

\author{
TOM JACK
}

In this article, I document the introduction and development of gospel music within the African-American Christian community of Omaha, Nebraska. The 116 predominantly black congregations in Omaha represent twenty-five percent of the churches in a city where African-Americans comprise thirteen percent of the overall population. ${ }^{1}$ Within these institutions the gospel music genre has been and continues to be a dynamic reflection of African-American spiritual values and aesthetic sensibilities. By focusing the research on perceptions and descriptions provided by

Tom Jack is an adjunct faculty member at the College of Saint Mary, Omaha and Lincoln, where he teaches courses in ethnomusicology and the history of jazz and rock $\mathcal{E}$ roll.

[GPQ 20 (Summer 2000): 225-34] the music's practitioners, an examination of this genre at the local level will shed insight into the development and dissemination of gospel music on the broader national scale.

Following an introduction to the gospel genre, the character of sacred music in Omaha's African-American Christian institutions prior to the appearance of gospel will be examined. Next, the city's male quartet practice will be considered. Factors that facilitated the adoption of gospel by "mainstream" congregations during the 1930s and 1940s will then be addressed. In conclusion, the role of Salem Baptist Church as a focal point and instigator of musical change from the 1950 s to the present will be described.

The accepted definition of the word "gospel," as found in the Oxford English Dictionary, reads, "the glad tidings (of the Kingdom of God)' announced to the world by Jesus Christ. Hence, the body of religious doctrine taught by Christ and His apostles; the Christian revelation, religion or dispensation." This definition also describes the word as "short for gospel music [italics in the original]." Gospel music in the tradition of black Christianity, the subject of the effort at hand, has twice been given 
articulate and insightful definition by African-American scholar Pearl Williams-Jones, who wrote, "The term 'Afro-American gospel music' is used to refer to a particular body of contemporary black religious music which is the sum total of our past and present socioeconomic and cultural traditions. Afro-American gospel music is characterized by its use of texts of poetic imagery, poly-rhythms with strong emphasis upon syncopation, melodies based upon the traditional 'blues scales' (which consists of the lowered thirds, fifths, and sevenths) and European harmonies." 3 She elaborated on the cultural ethos a few years later, saying, "Black gospel music, a synthesis of West African and Afro-American music, dance, poetry and drama, is a body of urban contemporary black religious music of rural folk origins which is a celebration of the Christian experience of salvation and hope. It is at the same time a declaration of black selfhood which is expressed through the very personal medium of music." 4

Gospel music today is the latest stage in a musical continuum whose foundation was in place over one hundred years ago. The first African-American denomination was the African Methodist Episcopal Church (A.M.E.), officially chartered in Philadelphia in $1816 .^{5}$ Its bishop, Richard Allen (1760-1831), had earlier compiled A Collection of Spiritual Songs and Hymns Selected from Various Authors by Richard Allen, African Minister (1801), the first hymnal designed specifically for use by African-Americans. ${ }^{6}$ The formal worship service of early African-American Protestantism relied on, for the most part, the same repertoire used in the white Protestant church. The works of the English composer, Isaac Watts (16741748), for example, were particularly well received, and to this day this body of hymns is simply referred to in the vernacular of the black church as the "Dr. Watts." The performance style was one of "lining-out," also called "surgesinging" or "long-meter," wherein a line of text is recited or sung by a leader and then sung in response by the congregation.?
Several of Watts's texts were incorporated for use in the spirituals, improvised hymns born of oral tradition and the first form of AfricanAmerican musical expression to achieve worldwide recognition. ${ }^{8}$ Beginning in 1871 , black colleges choirs such as the Jubilee Singers of Fisk University performed programs showcasing "arranged spirituals," formalized for the concert stage, to enthusiastic audiences in the United States and Europe. ${ }^{9}$ Professional singing troupes modeled after the college organizations later journeyed as far abroad as Africa, Australia, and Asia. ${ }^{10}$

Concurrent with the appearance of the college choirs, the tradition of male quartet harmonizing was a fixture of many AfricanAmerican communities by the 1870 s. "Jubilee quartets" were featured as subgroups within many of the Fisk Jubilee-type troupes, and by 1890 had surpassed these larger ensembles in popularity. ${ }^{11}$ Usually performing a cappella, the quartets gradually moved from a polished, homophonic texture toward a less restrained style that reflected vocal and rhythmic independence more characteristic of the folk church aesthetic. The rapid proliferation of these "gospel quartets" at the local level is attested to by the formalized quartet competitions that occurred during the 1920 s and 1930s. ${ }^{12}$

It is at this point that the impact of individuals becomes most apparent in the gospel repertoire. Jon Michael Spencer states that the first original hymn collection of the Transitional Period, or Pre-Gospel Era (1900-30), was published by Charles Price Jones in $1899 .{ }^{13}$ Philadelphia pastor Charles Albert Tindley (1851-1933) has long been credited as foremost of the early composers in the gospel tradition. ${ }^{14}$ While Tindley compositions such as "Stand By Me" and "The Storm is Passing Over" are standards in the contemporary gospel repertoire, the minister's most significant contribution may be the inspiration be provided as a musical model for the man generally considered to be "the father of gospel music," Thomas Dorsey. ${ }^{15}$ 
Thomas Andrew Dorsey (1899-1993) was born in the small rural community of Villa Rica, Georgia. As a youth, Dorsey had considerable exposure to sacred music. His father was an itinerant Baptist preacher and his mother a church organist. In spite of this religious background, Dorsey attained initial notoriety in the decidedly secular blues market of Chicago, accompanying and writing songs for such well-known performers as Gertrude "Ma" Rainey and Tampa Red (Hudson Whittaker). By 1929 Dorsey had abandoned popular music to focus exclusively on sacred compositions, imbued with musical sensibilities of blues and jazz, which he called gospel songs. ${ }^{16}$ Dorsey founded the Dorsey House of Music in 1932 and became the first independent publisher of black gospel. That same year, along with Magnolia Lewis Butts (ca. 18851949) and fellow Georgia native Sallie Martin (1896-1988), he established the National Convention of Gospel Choirs and Choruses in Chicago, chartered in 1939 and the first nationwide organization devoted to the genre. ${ }^{17}$ Aided greatly by the promotional efforts of Martin, Dorsey's songs were introduced not only into black churches from coast to coast but "by 1939, four of Dorsey's compositions were included in a songbook, printed in shape-notes, that was widely distribute in white [italics mine] evangelical congregations."18 Beginning in the forties, "Dorsey" became a generic term for any song in the gospel repertoire. ${ }^{19}$

In addition to the quartet tradition and the composition of new songs, a third element critical to the development of gospel was the musical practice found among the disparate congregations frequently grouped under the rubric of Holiness or Sanctified churches. ${ }^{20}$ Historically, the centrality of music within the Holiness service stands in sharp contrast to mainstream Baptist and Methodist practices. Pursuant to Pentecostal interpretation of Psalm 150, Holiness churches routinely incorporated musical instruments in the lifting of praise, a practice too "worldly and secular" for more institutionalized denominations. As
George Robinson Ricks has observed, "While the use of instruments was forbidden in the orthodox Negro church, their introduction by Holiness groups gave the music a 'different sound than just handclapping." 21 The commonplace piano and organ might be joined by drums, guitar, saxophone, harmonica, or any number of instruments, the whole augmented by the ubiquitous tambourines of the congregation. ${ }^{22}$

Considering the diversified instrumentation, the shadings of jazz and blues that permeated Pentecostal music is not surprising. Sanctified accompaniment was typified by the "stomping" approach of blind pianist Juanita Arizona Dranes of Texas, whose style drew on barrelhouse and other secular traditions. ${ }^{23}$ Popular music elements were in fact so pronounced that some saw Holiness music as "essentially the sacred counterpart of the blues, frequently the sacred text being the only distinguishing element." ${ }^{24}$ Examining musical change in black religious practice, John Wesley Work singled out the Holiness church as the place where "music is exploited to a degree that probably is not attained in any other denomination." ${ }^{25}$ Eventually, the aesthetic preferences of Sanctified musical expression "moved beyond the boundaries of the Holiness-Pentecostal churches into many mainline Black churches, ranging from Baptist to Catholic parishes. ${ }^{26}$

The First Territorial Census of Nebraska, taken in 1854, noted thirteen African-Americans among a total population of more than twenty-seven hundred. ${ }^{27}$ By 1860 the black population in the new state had grown to eighty-two with roughly one-fourth residing in Douglas County, the location of Omaha. ${ }^{28}$ During the fall of 1865 , a congregation of five members led by Reverend John M. Wilkerson organized the state's first black church, St. John African Methodist Episcopal. ${ }^{29}$ Over the following decades, immigration fueled by job availability in the railroad and meat-packing industries drove Nebraska's African-American population to more than ten thousand in $1920 . .^{30}$ By 1923 , the year the foundation of 
the present St. John A.M.E. was laid, the church that had begun with five people numbered over twelve hundred members. ${ }^{31}$

At the end of the 1930s, Omaha was home to at least forty-three African-American churches, most of which supported one choir that relied on a staple of hymns, anthems, and spirituals. ${ }^{32}$ Spirituals, in particular, were perceived as both a standard of musical excellence and a source of ethnic pride. A review of a 1940 concert at Zion Baptist judged spirituals "the songs most highly anticipated by the large and enthusiastic audience." ${ }^{33}$ The announcement of an upcoming May Day festival that same year requested of the eleven participating churches: "In order that special emphasis may be place on Negro music all choir directors are being urged to consider the use of Negro Spirituals for their individual choir presentations." ${ }^{34}$ Commentaries of the period suggest that performances of spirituals in Omaha, as elsewhere, were appraised from a perspective reflective of the Western classical aesthetic. In a prime example, Flora Pinkston's assessment of a local performance by the Fisk Jubilee Singers in 1940 observed, "[The pianist] played with the most artistic melodic expression that only a great artist could produce in tone. The singers sang with trueness of tone from forte to pianisimo. The obligato parts were sung with great control, which in itself produced beauty of tone." ${ }^{35}$

Flora Pinkston was a model music instructor of the time, referred to by the Federal Writers' Project as "Nebraska's foremost Negro teacher of piano and voice." 36 One accompanist who assisted her during the 1930s and 1940s states flatly, "Everybody knew Flora Pinkston was the best." 37 A graduate of the New England Conservatory of Music, she studied privately in Paris before opening the Pinkston School of Music in Omaha in 1908. The Pinkston motto was "Help me and I will help you," which meant they should adhere to a strict diet of European art music. ${ }^{38}$ Pinkston sternly discouraged the improvisation and lively accompaniment characteristic to gospel. One current minister of music recalls that when Pinkston found him improvising at a lesson in the 1950s, "She everything but beat me up. ... She says, 'You're playing by ear and I'm not gonna have it!" 39 Although for a short time Pinkston directed the choir at Pilgrim Baptist, the bulk of her activities was concentrated in the secular sphere. Her greatest impact came about through the numerous former pupils who continue to influence music ministry throughout the city.

Not surprisely, the churches most noted for their music in the 1930s and 1940s were the largest and longest established congregations. Among the Baptists, the choirs of Zion, Pilgrim, and Mount Moriah all had enviable reputations. However, no other music program of the time could match the notoriety of St. John A.M.E. The core of St. John's music program consisted of a Senior Choir directed by Pearl Gibson, a Men's Chorus and a Junior Chorus. Since the three sometimes united to perform as a mass choir, the church in effect, featured four choirs. ${ }^{40} \mathrm{~A}$ unique aspect of music at St. John was the instrumental accompaniment furnished by "the orchestral part of the choir," consisting of a full string section, flute, clarinet, trumpet, and saxophone, plus the church's pipe organ. ${ }^{41}$

Pearl Gibson and the Senior Choir gained citywide renown for their performances of anthems, cantatas, and even operettas. Each of the up to eighty singers in the Senior Choir was able to read music. The annual Christmas performance of Handel's Messiah filled the spacious church to overflowing, and the reputation of the choir's a cappella renditions equaled that of the orchestral works. ${ }^{42} \mathrm{Ap}$ pearing on radio and described in newspaper accounts as "peerless," Pearl Gibson and the Senior Choir set a standard for black congregations throughout the city. ${ }^{43}$

For many years, the single most important annual musical event among the AfricanAmerican community was the Goodwill Spring Musical, an interdenominational extravaganza held annually from 1934 until 1946. ${ }^{44}$ Founder L[uther] L. McVay, a Pullman porter and member of St. John A.M.E., saw as the purpose of 
the musicals "the bringing about of a closer relationship between the churches, the choirs, and the encouragement of the use of musical talents, the realization of which greatly adds to the value and dignity of the church." ${ }^{45}$

The Spring Musical was usually staged in late April, drawing crowds of several thousand to the City Auditorium. With up to fifteen Baptist and Methodist churches participating, the mass choir boasted as many as 350 singers. Programs were devoted entirely to hymns, anthems, and spirituals learned from sheet music and memorized for the performance. In addition to pieces performed by the massed voices, the individual choirs normally rendered one selection each. The soloists, accompanists, and directors for the mass choir were the most well know and respected in the city. Despite the Christian theme of the assembly and the liturgical nature of the music, the Spring Musical was viewed by many who took part as more of a civic or social event than a religious one. In light of the biracial attendance, it also provided the black community a forum for the presentation of ethnic identity.

The path by which gospel music attained the form of a distinct genre owes a large debt to a preexisting, often secular quartet tradition in place by the 1870 s. ${ }^{46}$ Newspaper accounts of the 1930s attest to the vitality of the quartet practice in Omaha. Popular Southern groups such as the Soul Stirrers from Texas and the Kings of Harmony from Alabama made visits there, influencing the twenty-five or more groups active locally. As one consultant recalls, "churches needing money for expansion programs would bring these various other quartets of renown up and they would put on their programs, and then our quartets would catch on." ${ }^{47}$

Most important of the Omaha quartets was the Loving Four of Mount Calvary Community Church, whom scholar Horace Boyer calls "one of the first gospel groups to use guitar accompaniment." 48 Gospel researcher Lynn Abbott declares the Loving Four "one of the earliest full-time independent professional traveling gospel quartets." 49 Formed by
Evlondo Cooper and including two of his brothers, they started out performing secular songs as the Cudahy Quartet. The name is reference to Cudahy Packing Company where all of the members, as well as their musical trainer, were employed. Following their conversion to a gospel repertoire and a name change in the early 1930s, the Loving Four toured throughout the South and from Texas to Illinois, developing a reputation for emotionally charged performances. Bass singer Paul Briggs, a former member of the famous Wings Over Jordan ensemble, recalls, "The famous Cooper brothers were something else. ... When you'd run into them out there on the road, everywhere a group was appearing, if they happened to be passing through that section of the country at that time and they didn't know who the Cooper brothers were, or the Loving Four, you believe one thing: that when they left there they knew who they were." 50 The group eventually located their base of operations in New Orleans, where Evlondo heeded a call to the ministry and founded the Loving Four Baptist Tabernacle sometime before $1942 .{ }^{51}$

The Loving Four being an exception, most Omaha quartets limited their venues to area churches and meeting halls where quartet programs were held regularly on Sunday afternoons or evenings. Relations between clergy and quartets were frequently contentious, and rarely would a group be asked to sing at Sunday morning worship. Consultants report that some ministers questioned the motivation and moral character of quartets. Financial concerns may have been a further consideration, since services involving a full choir allowed greater participation and thereby larger attendance.

As public appetite for quartet singing led to more elaborate presentations of local groups, church service organizations such as women's and ushers' guilds staged occasional quartet contests or "battles" where eight or ten units would vie for a prize. ${ }^{52}$ If the function was held at a church to help raise funds, a conventional collection was generally taken during intermission. Most of the money went to the 
church, with a nominal amount given to the participating singers. The largest events, called "quartet jamborees," featured over a dozen groups in a single program lasting about three hours and were often held at the YMCA or CIO Union Hall. At these programs, a different procedure was followed. Knowing that each group had their own following, the jamboree sponsors would schedule the most popular quartets toward the end of the program in order to hold the crowd. Audience response was used as an indicator to choose two finalists from among the participants. Two collection tables would then be set up and the audience would file past, donating to the plate of whichever group they preferred. The one that solicited the larger donation was declared the winner. ${ }^{53}$

Throughout the 1950s, quartet promoter Rowena Moore sponsored a series of noncompetitive jamborees know as Musical Fiestas. As a packing-house employee and secretary of the union local, Moore received free use of the CIO Union Hall and thereby benefitted from the workplace affiliation characteristic common to the quartet tradition. According to Moore, the name "fiesta" was intended to recognize and appeal to the growing number of Mexican immigrant in the packing plant labor force. The Musical Fiestas featured as many as sixteen quartets, including female groups. ${ }^{54}$

By the 1960s the quartet practice in Omaha was a shadow of what it had been a decade earlier. Consultants blame the changing tastes of youth, whose preference shifted to secular music and entertainers, and the rise of large gospel choirs for the quartets' decline in popularity..$^{55}$ At present, the last remaining vestiges of quartet singing in Omaha are found in the city's "male choruses." Most notable of these is the Hub of Harmony II of Sharon Seventh-Day Adventist Church, an ensemble that draws primarily on the traditional quartet repertoire and emulates the a cappella style of performance.

The presentation of gospel music by full choirs took root in Omaha during the 1930s and gathered momentum throughout the 1940s. Appearances by gospel groups from outside the city won converts to the idiom and provided necessary performance models for local church musicians. As accompanist Eleanor Luckey relates, "When a congregation would hear these singers, this is when they wanted to change over to the new gospel. Because it was electrifying. It was ... spiritfilled, and they enjoyed that feeling." ${ }^{56}$ Methodist adoption of the gospel repertoire lagged far behind that of their Baptist counterparts. Yet even among the Baptist community, the degree and manner of gospel's integration was often idiomatic to the institution. Initially hindered by the genre's status as an imported commodity and further fragmented by denominational barriers, the acceptance of gospel music into the established liturgy was a multifaceted process that drew upon resources to which a number of congregations had access.

The seminal gospel songs of Thomas Dorsey and others of the 1930s were first demonstrated at the National Baptist Convention and $\mathrm{Na-}$ tional Convention of Gospel Choirs and Choruses held in Chicago. There, choir directors from throughout the country could learn songs and purchase sheet music for use in their own churches. But few Omaha directors were able to attend these events and area music stores did not stock the new gospel. This need was met at the grassroots level by Reverend Willis E. Fort of Salem Baptist Church and Roscoe Knight of Zion Baptit, each of whom sold gospel sheet music out of his home. Their service made the music available locally and kept the black church community apprised of trends in Chicago and elsewhere. More importantly, by selling to "whosoever will," as one consultant put it, they facilitated the spread of gospel to other Baptist congregations and, notably, across denominational borders.

In the winter of 1938-39, an alliance of four Methodist ministers conceived a community wide worship service that would endure until the late 1950s. The Union Services, as they were known, were held on Sunday evenings from January to April. With attendance 
ranging from seven hundred to one thousand, the location rotated among the largest churches in the city. Under the format employed, the responsibility for each Union Service was assumed by a church other than the week's host institution, regardless of either's governing affiliation. In other words, a Union Service held at church A must be conducted by the minister and choir of church $B$, or church $\mathrm{C}$, etc. In an article with the subheading "Denominational Bars Fall as Christendom Move Forward," the Omaha Star assessed the impact of this formula, saying, "The Union Services ... have proved so popular that denominational bars have faded and we now find a harmonious setting of Methodist, Baptist, and Presbyterian worshiping under one roof." 57 Contributors to this research confirm that in addition to communal fellowship, the Union Services were valued as an opportunity to experience the worship music of other congregations. In the context of the city's developing gospel music complex, they represented a temporary bridging of both intra- and, especially, interdenominational differences that opened avenues for diffusion of the genre.

Salem Baptist Church was founded in 1922. Before the mid-1940s, there was little to distinguish Salem from other churches of the community. Attendance in no way rivaled that of St. John A.M.E. or the larger Baptist congregations at Zion, Mount Moriah, and Pilgrim. Never a regular participant in the Union Services, the Salem congregation maintained a schedule of three Sunday services with music furnished by the adult senior choir. A second ensemble, the children's Rosebud Chorus, was added around $1938 .{ }^{58}$ The church was led by a series of clergy with the aforementioned music vendor Reverend Fort sometimes serving as interim pastor.

Reverend J. C. Wade came to Salem in 1944, having served the previous nine years pastoring in Memphis, Tennessee. His first sermon was delivered to a congregation of eighty-eight people. At the time of his retirement in 1988, the church boasted more than thirty-two hundred members, making it the largest of Omaha's black religious institutions. ${ }^{59}$ The remarks of his daughter, Doretha Wade-Wilkerson, shed some light on this stunning growth. As she explains, "It's kind of like two things that are important in the Black church. That's music and the Word. . . . First of all, is the preacher capable of giving me what the Word says, and then, is the choir capable of giving me what I need to be uplifted? So those two things go hand in hand." 60 Comments obtained in interviews confirm that the content, style, and sheer power of Reverend Wade's oratory certainly held a strong appeal for many. Yet, Wade himself recognized "They come for two reasons. Either ... they like his preaching, or they like the choir's singing." 61

The success of Reverend Wade's evangelism was abetted by this cognizance of music's high premium, in particular its potential for attracting and holding youth to the church. A movement to capitalize on this awareness was initiated almost immediately with the establishment of a new teenaged Junior Choir prior to the close of World War II. ${ }^{62}$ Salem's next ensemble, the Number 2 Choir composed of young adults, was organized sometime during 1946 or 1947 . Although an inspiring and perceptive minister, Reverend Wade was not himself a musician. His efforts to expand the music program benefitted greatly in this respect from the vitality of Elma Wells, a musician at Salem since 1934 who chose a fresh and invigorating repertoire. Under her direction, the Number 2 Choir soon established itself as the most contemporary choir in the city.

In 1951 Reverend Wade founded what would become Salem's premiere ensemble, the Inspirational Choir. His gifted daughter, Doretha, assumed leadership of the group in 1959 at the age of eighteen. The father-daughter ties between cleric and choir director insured a uniquely close communication that freed Reverend Wade from the distraction of extraneous responsibility with the choirs. Elma Wells recalls, "With the pastor approving of it, and her being interested in it, it just took off like wildfire." ${ }^{\prime 63}$ 
Seeking further musical complement to her father's ministry, about 1960 Doretha introduced complex choreography to the choir processionals that opened services. The choir began to tour to outlying communities in Nebraska. Through subsequent programs such as a 1967 concert appearance in predominantly white Crookson, Minnesota, the renown of the choir spread to regional proportions. The conventional instrumentation of piano and Hammond organ expanded with the addition of a drummer about 1971, possibly the first use of a trap set by an Omaha Baptist church. Electric guitar, electric bass, and saxophone were all added over the next few years. A vanity album was recorded in the Salem Baptist Church sanctuary in $1977 .{ }^{64}$ Further recording efforts of the Inspirational Choir benefitted from Reverend Wade's personal relationship with the late gospel superstar James Cleveland, with whom he had become acquainted in the 1970 s. Cleveland was so impressed by a performance in 1978 that he offered to record with them. The collaboration, "I Don't Feel No Ways Tired: James Cleveland Presents the Salem Inspirational Choir" (Savoy DBL 7024, 1978), was nominated for a Grammy Award in 1979. ${ }^{65}$

Stimulated by the example of Salem Baptist, the preference for contemporary gospel was evidenced in an increasingly greater number of congregations throughout Omaha. Speaking of the early 1960s, one prominent minister of music describes the Salem music program as "a focal point, as far as the direction of music at that time. ... Most people just decided they were either gonna get with it or die." $" 66$

"Getting with it" might have been especially difficult for music programs such as that at St. John A.M.E., which under Pearl Gibson had built a reputation on the strength of their formal anthems. ${ }^{67}$ Perhaps it is only natural that after Gibson's passing in the late 1950s, it was a Baptist, Lester Corbin, who guided them through the transition. Favoring a bolder type of gospel than that to which the church had been accustomed, Corbin introduced the mu- sic of James Cleveland and other contemporary composers whose sheet music he purchased from Roscoe Knight.

Of Omaha's historically African-American Methodist institutions, one of the last to incorporate modern gospel was Clair Memorial United Methodist Church. ${ }^{68}$ As at Salem, where Reverend Wade had been a catalyst, the "conversion" was motivated by a minister who came to Omaha from Memphis in 1971, Reverend Charles Young. Revitalization of the music program became early on a priority of his ministry. Under the direction of Reverend Young's wife, Marlene, a choir christened the Joyful Sounds debuted in 1972, complete with drums and a choreographed processional. Remembering the initial response of many congregants charter member, Carolyn Solomon recalls, "They didn't like it. I think that they were afraid of it. . . It was like we were turning the church into a dance hall." ${ }^{69}$ In time, however, reservations about the Joyful Sounds' choreography and percussion were abandoned, and both the stylistic practices and expanded instrumentation became permanent fixtures of Clair services.

Over the past two decades, performance of gospel music in Omaha has extended beyond the boundaries of church-specific organizations. Both Creighton University and the University of Nebraska at Omaha have sponsored gospel choirs, as have a few of the city's high schools. A half-dozen or so independent ensembles appear regularly at special events such as church anniversary programs. At present, the city's most conspicuous independent exponent of gospel is the Omaha Mass Choir. Directed by Jay Terrell, the 150 members of this ensemble represent at least twentyseven congregations, leaving no doubt that gospel music is alive, well, and widespread in Omaha. ${ }^{70}$

\section{REFERENCES}

1. "Black Churches Celebrate Their Role," Omaha World-Herald, 16 February 1991, 53-54.

2. Oxford English Dictionary, 2d ed., s.v. "gospel." 
3. Pearl Williams-Jones, "Afro-American Gospel Music: A Brief Historical and Analytical Survey (1930-1970)," in Development of Materials for a One-Year Course in African Music for the General Undergraduate Student, ed. Vada E. Butcher (Washington, D.C.: US Department of Health, Education, and Welfare, 1970), p. 202.

4. Pearl Williams-Jones, "Afro-American Gospel Music: A Crystallization of the Black Aesthetic," Ethnomusicology 19, no. 3 (1975): 376.

5. Eileen Southern, "Afro-American Music," in New Grove Dictionary of American Music, ed. H. Wiley Hitchcock and Stanley Sadie (London: Macmillan, 1986), vol. 1:14.

6. Eileen Southern, The Music of Black Americans: A History, 2d ed. (New York: W. W. Norton, 1983), p. 75.

7. Paul Oliver, "Spirituals," in New Grove Gospel, Blues and Jazz, by Paul Oliver, Max Harrison and William Bolcom (New York: W. W. Norton, 1986), p. 7; Paul Oliver, "Spiritual, §II, Black," in New Grove Dictionary of Music and Musicians, ed. Stanley Sadie (London: Macmillan, 1980), 18:4; William H. Tallmadge, "Dr. Watts and Mahalia Jackson: The Development, Decline, and Survival of a Folk Style in America," Ethnomusicology 5, no. 2 (1961): 95-99 passim.

8. Dena J. Epstein, "Black Spirituals: Their Emergence into Public Knowledge," Black Music Research Newsletter 8, no. 2 (1990): 5-8 passim; Southern, Music of Black Americans (note 6 above), p. 227.

9. Portia K. Maultsby, "Africanisms in AfricanAmerican Music," in Africanisms in African-American Culture, ed. Joseph Holloway (Bloomington: Indiana University Press, 1990), p. 186; Southern, ibid., p. 451.

10. John Lovell, Black Song: The Forge and the Flame (1972: reprint, New York: Macmillan, 1986), pp. 402-22; Southern, "Afro-American Music," (note 5 above), pp. 13-21.

11. Doug Seroff, "On the Battlefield: Gospel Quartets in Jefferson County, Alabama," in Repercussions: A Celebration of Afro-American Music, ed. Geoffrey Haydon and Dennis Marks (London: Century Publishing, 1985), pp. 32-33.

12. Ray Allen, "African-American Sacred Quartet Singing in New York City," New York Folklore 14, nos. 3-4 (1988): 10; Horace Clarence Boyer, "Tracking the Tradition: New Orleans Sacred Music," Black Music Research Journal 8, no. 1 (1988): 138.

13. Jon Michael Spencer, Protest and Praise: Sacred Music of Black Religion (Minneapolis: Fortress Press, 1990), p. 208.

14. Horace Clarence Boyer, "Charles Albert Tindley: Progenitor of Black-American Gospel
Music," The Black Perspective in Music 11, no. 2 (1983): 103-32 passim.

15. Horace Clarence Boyer, "Tindley, Charles Albert" in New Grove Dictionary of American Music (note 9 above), 4: 395; J. Jefferson Cleveland, "A Historical Account of the Black Gospel Song," in Songs of Zion, ed. J. Jefferson Cleveland and Verolga Nix (Nashville: Abingdon, 1981), p. 172 [4 pp.]; Arna Bontemps, "Rock, Church, Rock," reprinted in The Negro in Music and Art, ed. Lindsay Patterson (New York: Publishers Company, 1942); pp. 7881.

16. Bernice Johnson Reagon, "Pioneering African American Gospel Music Composers: A Smithsonian Institution Research Project," in We'll Understand It Better By and By, ed. Bernice Johnson Reagon (Washington, D.C.: Smithsonian Institution, 1992), p. 15.

17. Horace Clarence Boyer, "An Analysis of His Contributions: Thomas A. Dorsey, 'Father of Gospel Music'," Black World 23, no. 9 (1974): 25-26.

18. Anthony Heilbut, The Gospel Sound: Good News and Bad Times, rev. and updated (New York: Harper and Row, 1985), pp. 7-9; Heilbut, "The Secularization of Black Gospel Music," in Folk Music and Modern Sound, ed. William Ferris and Mary L. Hart (Jackson, Miss.: University Press of Mississippi, 1982), p. 107.

19. Boyer, "Analysis" (note 16 above), p. 28; Richard Alan Waterman, "Gospel Hymns of a Negro Church in Chicago," International Folk Music Journal 3 (1953): 87-93; John Wesley Work, "Changing Patterns in Negro Folk Songs," Journal of American Folklore 62, no. 244 (1949): 141-42.

20. C. Eric Lincoln and Lawrence H. Mamiya, The Black Church in the African American Experience (Durham, N.C.: Duke University Press, 1990), p. 77. Other denominations frequently considered Holiness churches include Pentecostal, Apostolic, Spiritual, and Church of God in Christ.

21. George Robinson Ricks, Some Aspects of the Religious Music of the United States Negro (New York: Arno Press, 1977), pp. 131-32.

22. Oliver, Songsters and Saints: Vocal Traditions on Race Records (Cambridge, U.K.: Cambridge University Press, 1984), pp. 173-197 passim; Southern, Music (note 6 above), p. 448.

23. Oliver, ibid., pp. 176, 189.

24. Southern, (note 6 above), p. 449.

25. Work, "Changing" (note 18 above), p. 140.

26. Portia K. Maultsby, "The Use and Performance of Hymnody, Spirituals and Gospels in the Black Church," Western Journal of Black Studies 7, no. 3 (1983): 168.

27. Dorothy Devereux Dustin, Omaha and Douglas County: A Panoramic History (Woodland Hills, Calif.: Windsor Publications, 1980), p. 19. 
28. James D. Bish, "The Black Experience in Selected Nebraska Counties, 1854-1920" (thesis, University of Nebraska at Omaha, 1989), p. 16.

29. "St. John AME Church 125th Anniversary," Omaha Star, 24 May 1990, 5.

30. Lawrence H. Larsen and Barbara J. Cottrell, The Gate City: A History of Omaha (Boulder, Colo.: Pruett Publishing Company, 1982), p. 168.

31. "Historical St. John AME Church," Omaha Star, 7 June 1990, 6.

32. Ida Madonna Rowland, "An Analysis of Negro Ritualistic Ceremonies as Exemplified by Negro Organizations in Omaha" (thesis, Municipal University of Omaha, 1938), p. 25.

33. "King Rich in Artisry" [sic], Omaha Star, 10 May 1940, 5.

34. "Fourth Annual May Day Festival to Present Outstanding Youths in Music," Omaha Star, 26 April 1940, 1.

35. "The Fisk Jubilee Singers," Omaha Star, 6 December 1940, 1.

36. Federal Writers' Project, Works Progress Administration, The Negroes of Nebraska (Omaha: Omaha Urban League Community Center), p. 43.

37. Bertha Young Meyers, interview with author, Omaha, Nebr., 6 August 1990.

38. "Assistant Teachers in Normal Department," Omaha Star, 4 October 1940, 1.

39. Michael Dryver, interview with author, Omaha, Nebr., 27 July 1990.

40. "Church Notices: St. John A.M.E. Church," Omaha Star, 27 September 1940, 3.

41. "Church Notices: St. John A.M.E. Church," Omaha Star, 4 November 1939, 3.

42. Dryver interview (note 38 above); Michael Dryver, interview with author, Omaha, Nebr., 30 July 1990.

43. "Business Support Imperative for Economic Uplift," Omaha Star, 25 October 1940, 1; Meyers interview (note 36 above).

44. Paul Briggs, interview with author, Omaha, Nebr., 25 June 1991.

45. "7,000 Expected to Witness Annual Spring Musical," Omaha Star, 24 April 1942, 1.

46. James Weldon Johnson and J. Rosamond Johnson, The Book of American Negro Spirituals (New York: Viking Press, 1925-27), p. 35.

47. Raymore Davis, interview with author, Omaha, Nebr., 17 August 1990.

48. Boyer, "Tracking" (note 11 above), p. 140. 49. Lynn Abbott, "The Soproco Spiritual Singers: A New Orleans Quartet Family Tree," mono- graph, (New Orleans: Jean Lafitte National Historical Park, 1983), pp. 47-54.

50. Briggs interview (note 43 above).

51. Rev. J. C. Wade, interview with author, Omaha, Nebr., 1 August 1990; Historical Records Survey, Directory of Churches and Religious Organizations in New Orleans, prepared by Historical Records Survey, Division of Community Service Programs, Works Progress Administration (Baton Rouge, La.: Louisiana State University, 1941), p. 28.

52. "The Freezers Club," Omaha Star, 5 August 1939, 4.

53. Fred Knight, interview with author, Omaha, Nebr., 28 June 1991.

54. Rowena Moore, interview with author, Omaha, Nebr., 12 July 1991.

55. Paul Briggs, interview with author, Omaha, Nebr., 24 July 1991; Dryver interview (note 41 above).

56. Eleanor Luckey, interview with author, Omaha, Nebr., 22 August 1990.

57. "Union Services to Begin Again Sunday, January 4," Omaha Star, 2 January 1942, 1.

58. Pauline Smith, interview with author, Omaha, Nebr., 11 July 1991; Pauline Smith, interview with author, Omaha, Nebr., 11 June 1990.

59. Wade interview (note 50 above).

60. Doretha Wade-Wilkerson, interview with author, Omaha, Nebr., 11 July 1991.

61. Wade interview (note 50 above).

62. Ibid.

63. Elma Wells, interview with author, Omaha, Nebr., 27 June 1991.

64. "Salem Baptist Church Inspirational Choir History," frontispiece in "Salem Baptist Church Inspirational Choir 40th Reunion 1951-91," commemorative booklet issued at Salem Inspirational Choir's 40th Reunion-Anniversary Concert, 13 July 1991; Mark Poindexter, interview with author, Omaha, Nebr., 11 July 1990; Wade interview (note 50 above).

65. "21st Annual Grammy Awards Final Nominations," Billboard, 20 January 1979, 122.

66. Dryver interview (note 38 above).

67. Wells interview (note 62 above).

68. Pauline Smith, interview with author, Omaha, Nebr., 25 October 1991.

69. Caroline Solomon, interview with author, Omaha, Nebr., 22 August 1990.

70. Jason "Jay" Terrell, interview with author, Omaha, Nebr., 25 March 1999. 